\title{
HABANAPP: HAVANA'S ARCHITECTURAL HERITAGE A CLICK AWAY
}

\author{
C. Morganti ${ }^{1}$, C. Bartolomei ${ }^{1}$ \\ ${ }^{1}$ Department of Architecture, Alma Mater Studiorum University of Bologna, Bologna, Italy - (caterina.morganti4, \\ cristiana.bartolomei)@unibo.it
}

\author{
Commission II / WG II/8
}

KEY WORDS: App, Augmented Reality, Cultural Heritage, Low-cost system, La Habana, Cuba

\begin{abstract}
:
The research treats the application of technologies related with augmented and virtual reality to architectural and historical context in the city of Havana, Cuba, on the basis of historical studies and Range-Imaging techniques on buildings bordering old city's five main squares. The specific aim is to transfer all of the data received thanks to the most recent mobiles apps about Augmented Reality (AR) and Virtual reality (VR), in order to give birth to an innovative App never seen before in Cuba. The "Oficina del Historiador de la ciudad de La Habana", institution supervising architectural and cultural asset in Cuba, is widely interested in the topic in order to develop a new educational, cultural and artistic tool to be used both online and offline.
\end{abstract}

\section{INTRODUCTION}

For what is concerning historical investigation and surveys traditional techniques were employed, consolidated and consequently enriched thanks to the great amount of specificities collected during the survey exeperience itself, carried out in Havana's five main squares (Figure 1). "Structure for motion" and "Image-based modeling" processes were applicated as well. This specialised technique it's been in use for a long time in this field altough not in Cuba, as much as Augmented Reality (AR) and Virtual Reality (VR) are techological systems still very connected to modern devices with good margin for further development but almost uncovered here. At the contrary it is possible to observe some valuable examples of AR as well as VR taking into consideration other contexts, always considered as a great development field for research. Highexpectations on products like HTC Vive or Sony Playstation VR for example, together with a late entry in the market and a poor choice of products, raised some doubts on the forthcoming of this technology. Despite of that, enterprises keep on investing on this type of outcome. According to a research carried out by Tech Pro in 2016, the $67 \%$ of enterprises is planning to use AR and the $47 \%$ is considering to employ VR. A report launched by IDC (Internal Data Corporation), first institution in the world specialized in Market Research \& Analysis for technologies in digital innovation, supports that over the coming years we will assist to an explosive growth of incomes in AR/VR sector. Within 2020 incomes from the field will overcome 162 billion dollars, while those on AR/VR sofwares will increase as much as $200 \%$ every year. It is assumed that 2018 will represent a turning point for technologic market. Retails giants as multinationals like IKEA, North Face and Lowe's are utlizing AR and VR already, to sell and advertise their product completely transforming customer's experience. It is conceivable that the evolution of such a system could be transferred to tourism sector. Augmented Reality finds good application especially in mobile outdoor cultural flows. It became, among others technologies for studies, communication and spreading of cultural heritage, the most changing idea of having an "experience" which is dynamic, modern and involving at the same time. AR is specifically suitable to make the historical process of the building easy to understand. Its spread is mostly due to affordable costs and advanced technological level attributed to the latest mobile communication devices.

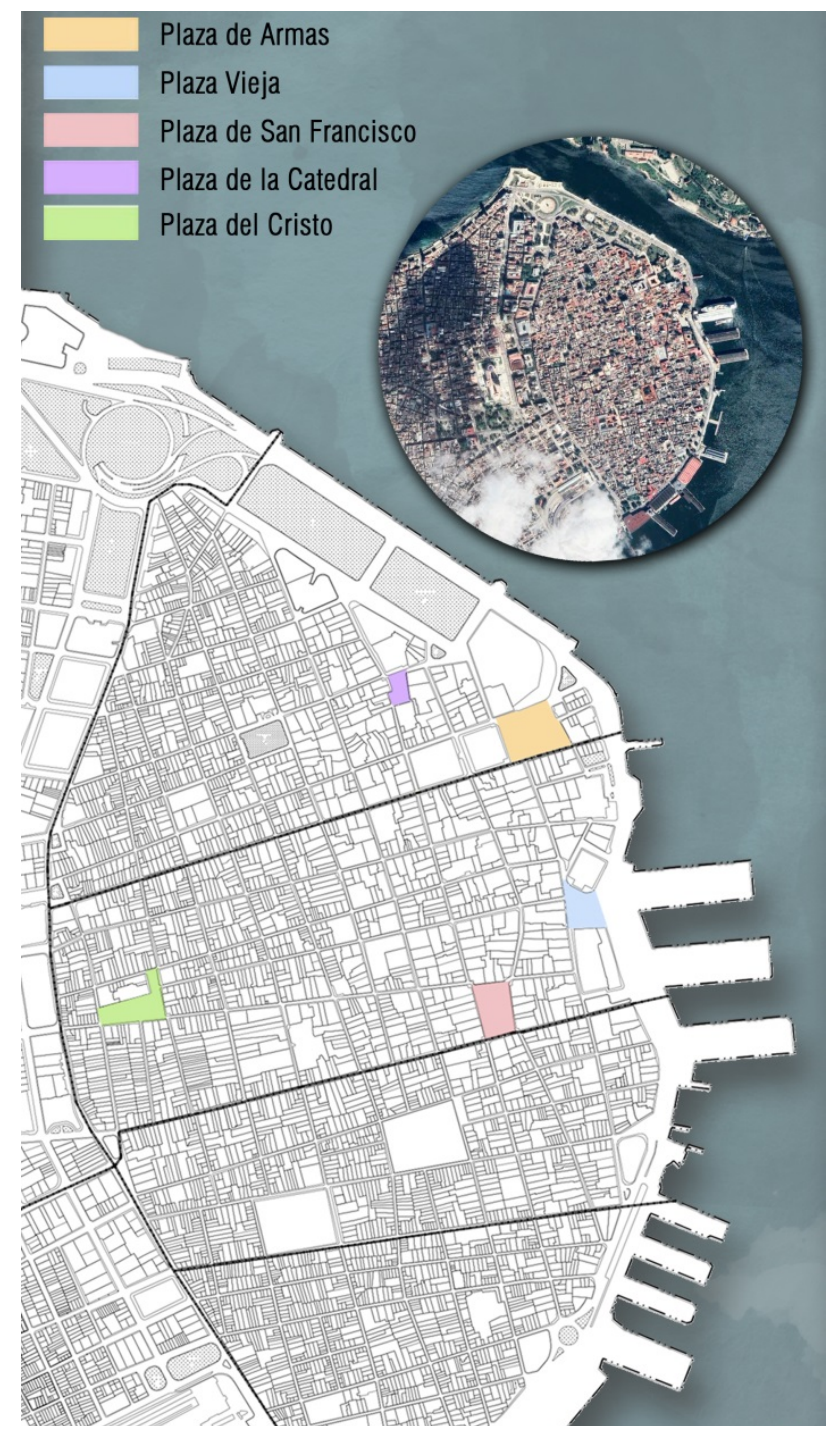

Figure 1. Havana's five main squares 
Examples of analogues applications proposed in the research are definitely not missing in Cuba squares (AA.VV., 2011), especially focusing on cultural enjoyment. In 2001, indeed, the first application instance appeared in a Museum with the Archeological Virtual Dig, consequently in 2005 the project Time Machine Navigation System was presented by Kyoto University. Considerable importance is to be attributed as well to three European Projects called EPOCH (European Research Network on Excellence in Processing Open Cultural Heritage), ARCHEOGuide (Augmented Reality based Cultural Heritage On-site GUIDE) e iTACITUS (Intelligent Tourism and Cultural Information through Ubiquitous Service). Other remarkable experimentation is the one carried out by Fraunhofer Institute for Computer Graphics Research IGD in 2010. It's about an installation made by a rotating screen positioned on a little column equipped with a camera which can transpose the facing image on the monitor; once recognized the figure, the device reports its virtual overlay. Such a system is situated in Amsterdam Allars Pierson Museum. A further example is represented by the app promoted by Spanish Government, MobiAr, designed both for citizens and tourists. Recently software and hardware developers pushed on experimentation and commercialization of blippAR systems which enable the identification of images and a subsequent overlapping of multimedia and interactional additional contents, together with hardware technologies allowing the user to experience various dimension and submersion on a virtual level. Those cutting edge devices are, for example, electronic glasses dedicated to augmented reality like Google Glass, GlassUp, Microsoft HoloLens and Sony SmartEyeGlass, or some futuristic hypertechnological eye lenses (Figure 2).

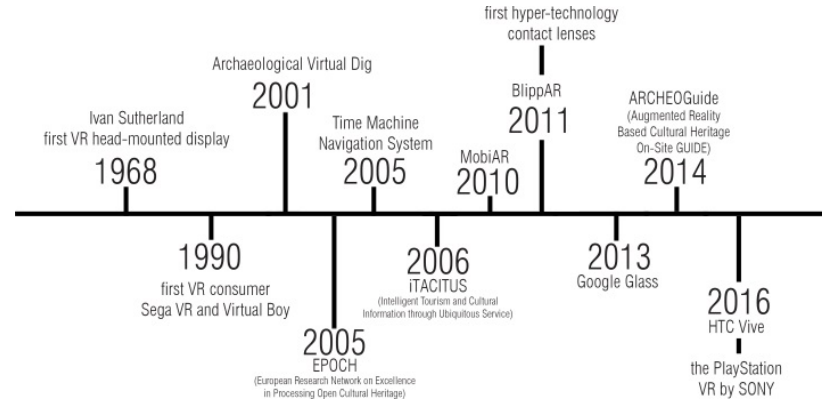

Figure 2. state of the art AR / VR

Such tools, showing more and more potential toward multimedia, recreational entertainment and more, will certainly become useful in cultural tourism context (Bonacini, 2011): downloading the pre-arranged apps will be enough to obtain additional information about places, monuments, artworks, in the very moment of direct observation (Bonacini, 2014). Tourism and business operators could take advantage of this innovative technology to evolve the means through which news and contents are conveyed, enriching the user's visual field thanks to new input and quite unprecedent stimulations.

\section{CUBA STATE OF THE ART}

Is there to say that for several reasons those technologies haven't yet been implemented in Cuban reality. First of all mobile phones recently approached the Country thanks to Italian Telecom exporting its technology to the local enterprise ETECSA. Thanks to a great request for mobile phones market the first pragmatic complexity was the adaptation of telephone network. Joined to such a technologic rush there was, on the other hand, economic obstacles and political resistance to internet connection facility. Only from 2015 it is possible to surf the web but only relying on Internet Point or touristic resorts, with some limits on the access and slow transmission speed compared to the service cost. Nowadays, for what is concerning Cuba, only touristic maps and offline apps are available and none of them implies augmented reality with specific technical and architectural materials. Currently the more advanced and employed smartphone apps are: Cuba Map, an application which helps with the individuation of geographical position, commercial activities and restaurant; Cuba Travel Guide featuring Havana, Varadero and more! Is a travel guide focused on the cities of Havana, Varadero and Santiago de Cuba. A further application is Cuba Tourism Guide which contains a best attractions list, a photographic gallery and clubs detection. Basically those apps contains traditional guide's materials and can just localize positions and attractions thanks to GPS connection. As a consequence of the almost impossible moving connection to the network such apps are exploited only precharging maps and archives for offline utilization. Obviously in such a way every chance of real time information updating is completely lost. Today Cuba's will of openness and the enormous touristic request recently occurred in the country offer good conditions for cultural tourism market to grow (Mohammed-Amin, 2010). For this reason an unstoppable development is expected for what is concerning HumanComputer Interaction for tourism's business benefit (Figure 3).
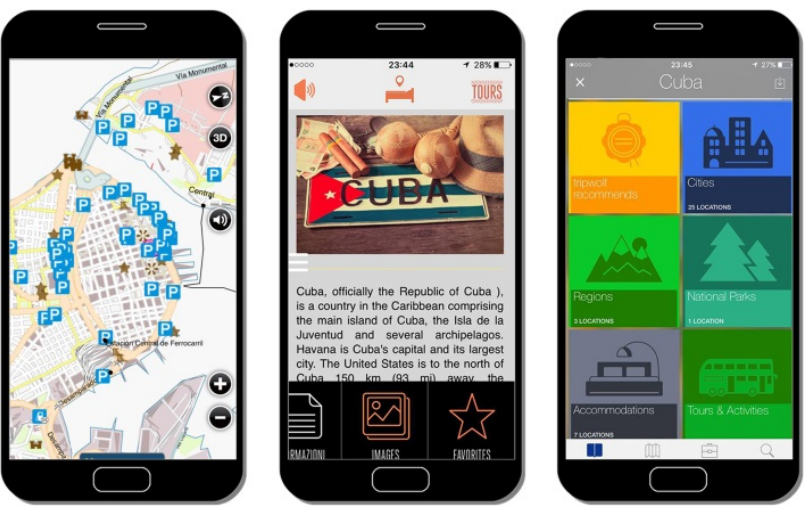

Figure 3. Cuba Map, Cuba Travel Guide featuring Havana, Varadero and more! and Cuba Tourism Guide

\section{ACHIEVED RESULTS AND APPLICATION DEVELOPMENT}

The study under consideration, aimed at the investigation for a procedural and methodological standard for survey and data storage nonetheless for the development of an AR/VR application in Cuban context, underlined potentiality and critical points found on the way. The analyzed system is that one which a tourist or a citizen owning an ordinary mobile device equipped with GPS could use. Due to the mobile internet connection in Cuba it is necessary to furnish a database containing all the useful information like maps, paths, photography, present and past 2D and 3D images predictable for the future in order to overlap them to live images. This tool can be implemented with audio tracks to make experiences and information deeper. In Cuba the quite absolute lack of connection to mobile internet network generally leads to an impossibility of access to real time information. Existing conditions therefore allows archives and database essential to the apps operability to be installed into devices or external storage, like for example micro-USB Pen Drive or dock input. Into the device other flash systems or memory cards, SD or micro-SD type, could also be inserted. 
They will have different storage capacity depending on the data quantity required to the app's different configurations, each one drawn up following the public needs. For example, they could be single maps with AR path's indication of the main monuments or thematic maps, or database with specification for many different fields of interest. The user will enjoy a flexibility of offer, since the app could be divided into packages in order to "personalize" the choices. That also allows, during the database creation, to segment the work and implement it progressively. The study on the five squares can be considered the first step of this common thread. HabanApp is the chosen name for the studied app and is symbolized by a stylized real palm, recognized by Cubans as the "fields'queen, its strong presence in the National Banner represent freedom and independence of the recently born Cuban republic, emblem of the bloom and fertility of his privileged soil (Figure 4). HabanApp is the first Augmented Reality app being developed for Cuba containing technical details about architecture (Figure 5).

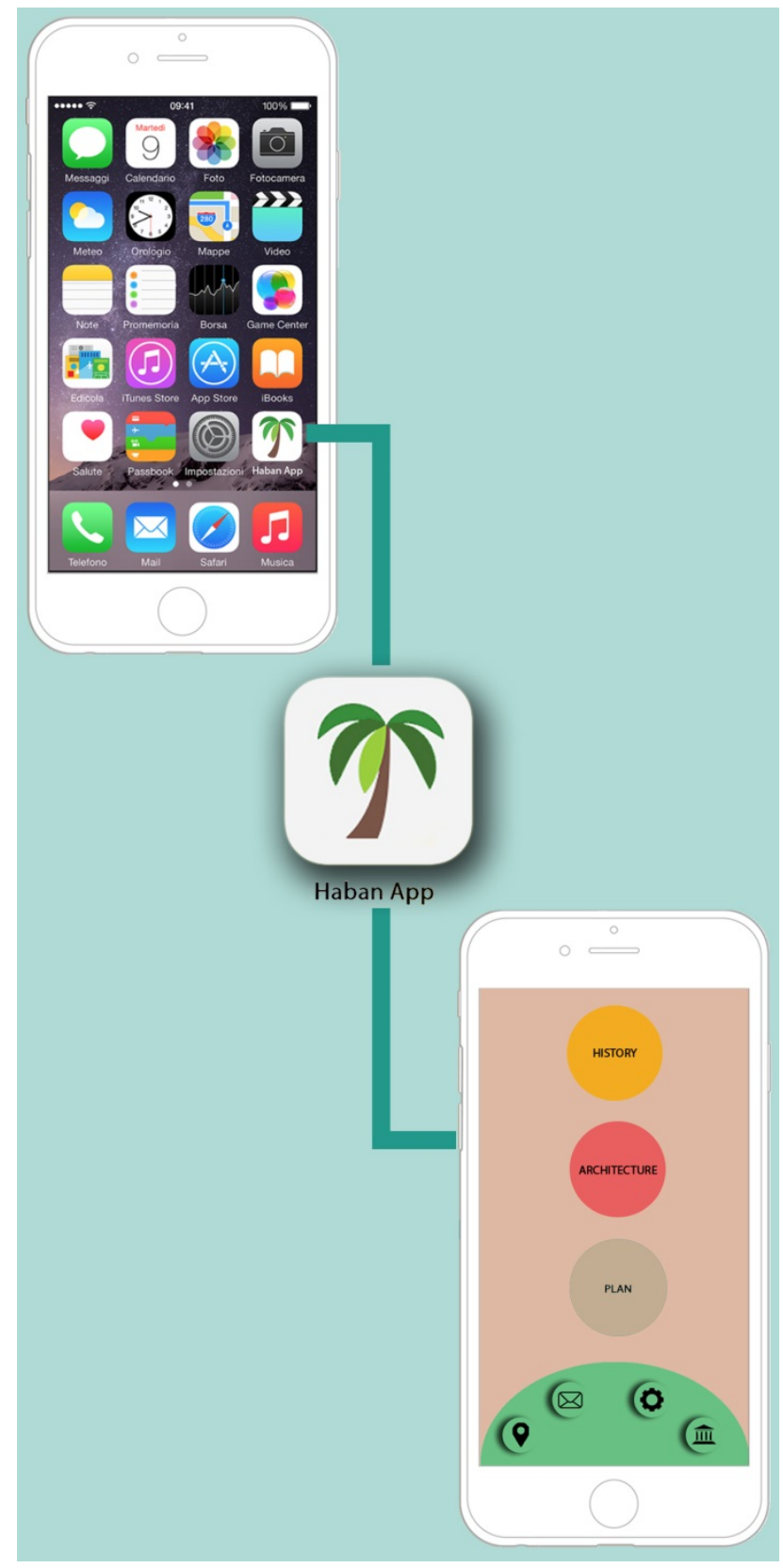

Figure 4. Example of a digital mockup - HabanApp
Currently the project is on its concept phase, when focused especially on innovation, new technologies, technical and scientific contents as well as its sustainability and improvability regarding specifically modern and future Cuban reality Guidelines which will assist the executive phase were defined behind the concept. During the app designation graphic aspects for communication were considered too, special consideration was given to developing stylistic choices. The ultimate goal is the pursue of new solutions improving the project and making it appropriate for every intended objective because of a catchy look. For this reason the most analyzed aspects were the application of AR technologies on architecture themes, software matching on different types of devices, pragmatism in using the tool considering different connections problems both online and offline, user friendliness thanks to an attractive and efficient graphic, implementation possibility on different topics and follow-ups using separate forms and low production costs, improvement and buying (Figures 6 to 16).

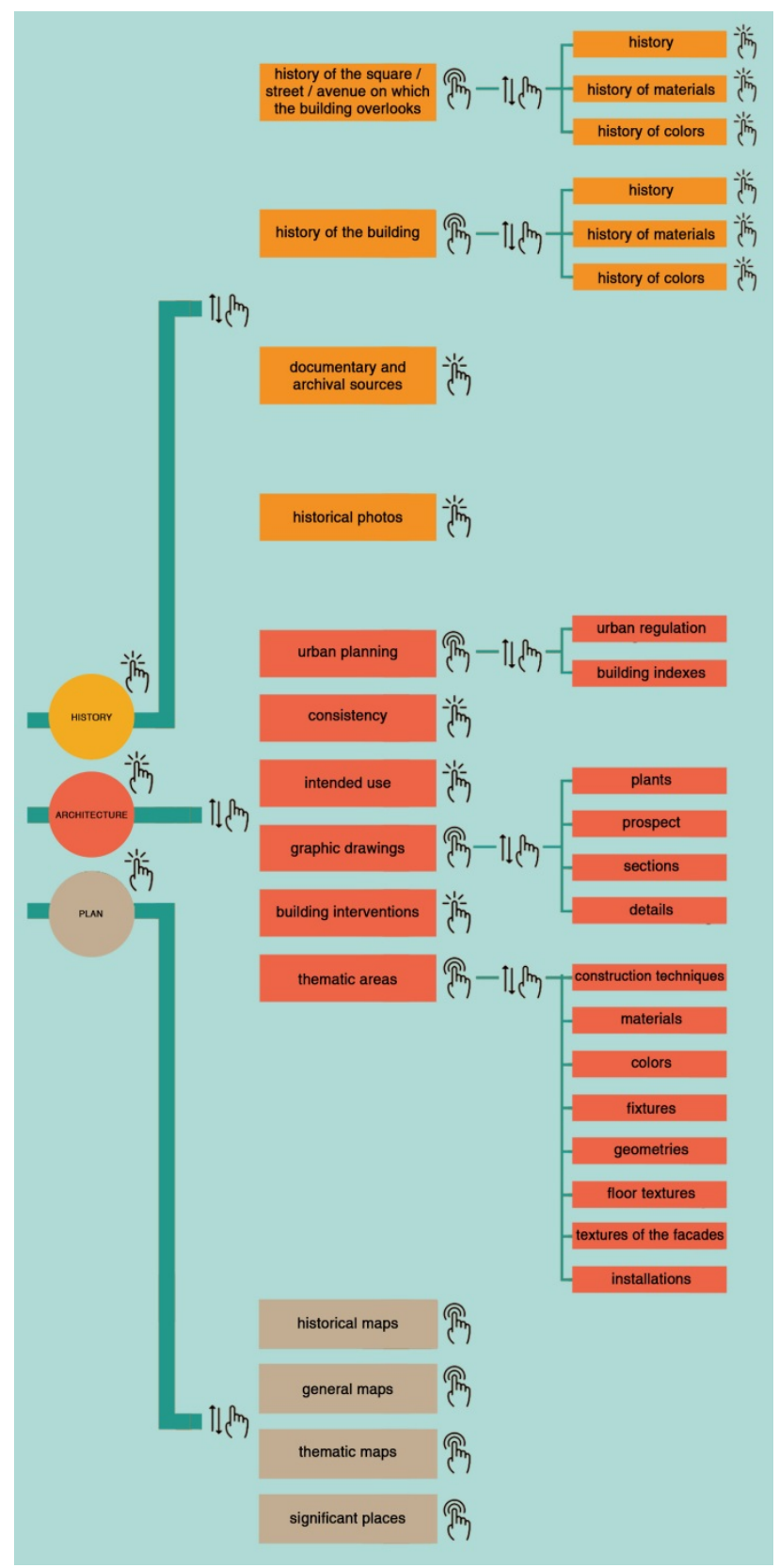

Figure 5. Contents of HabanApp 


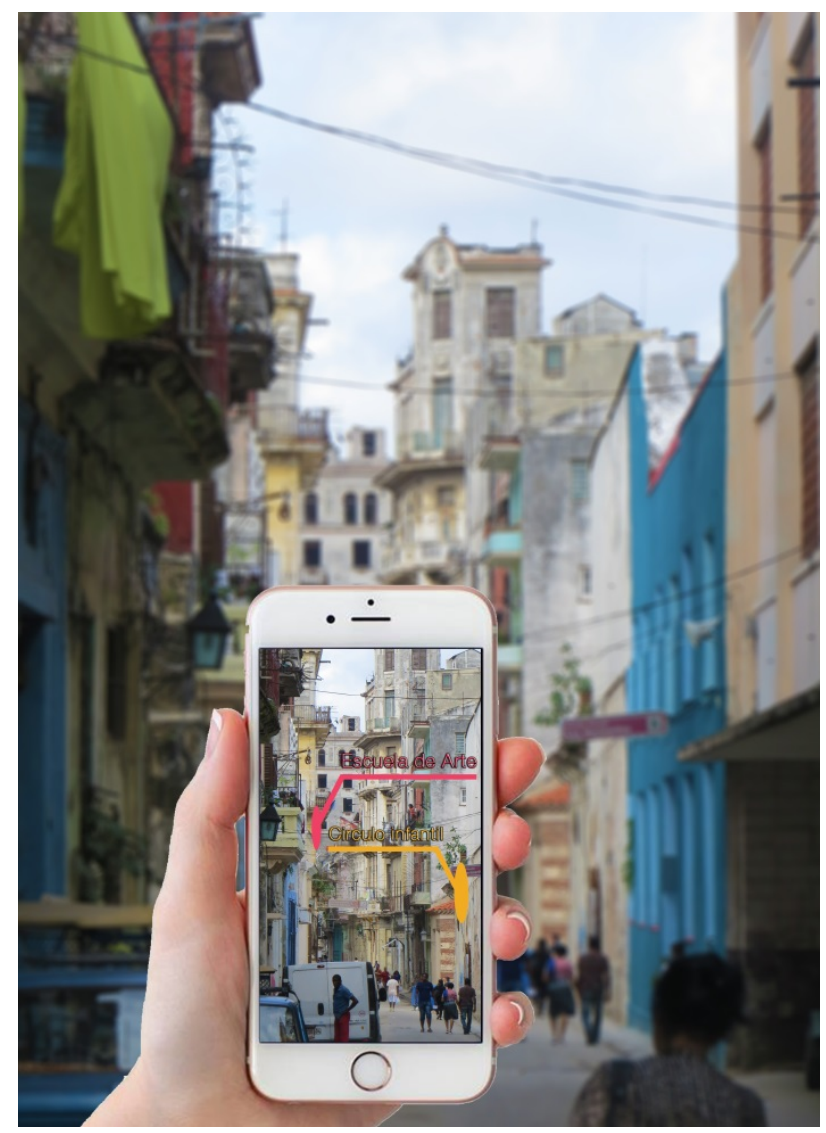

Figure 6. Example of an application of aumented reality
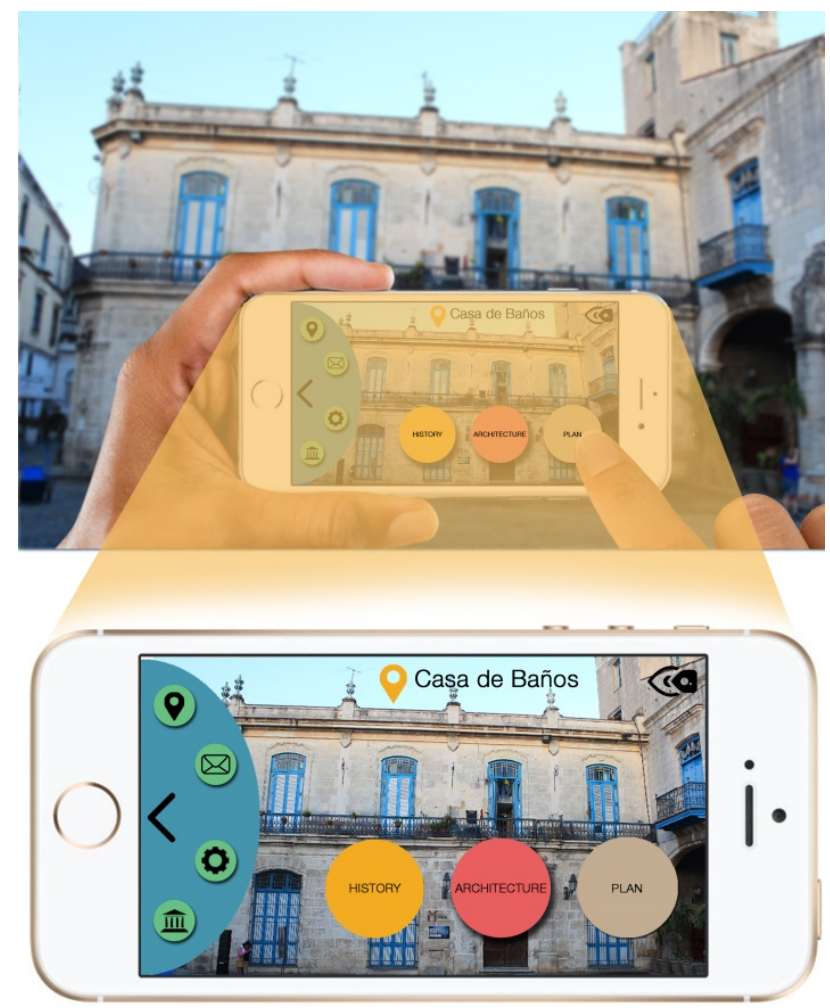

Figure 7. Example of an application of aumented reality (Casa de Baños - Plaza de la Catedral)

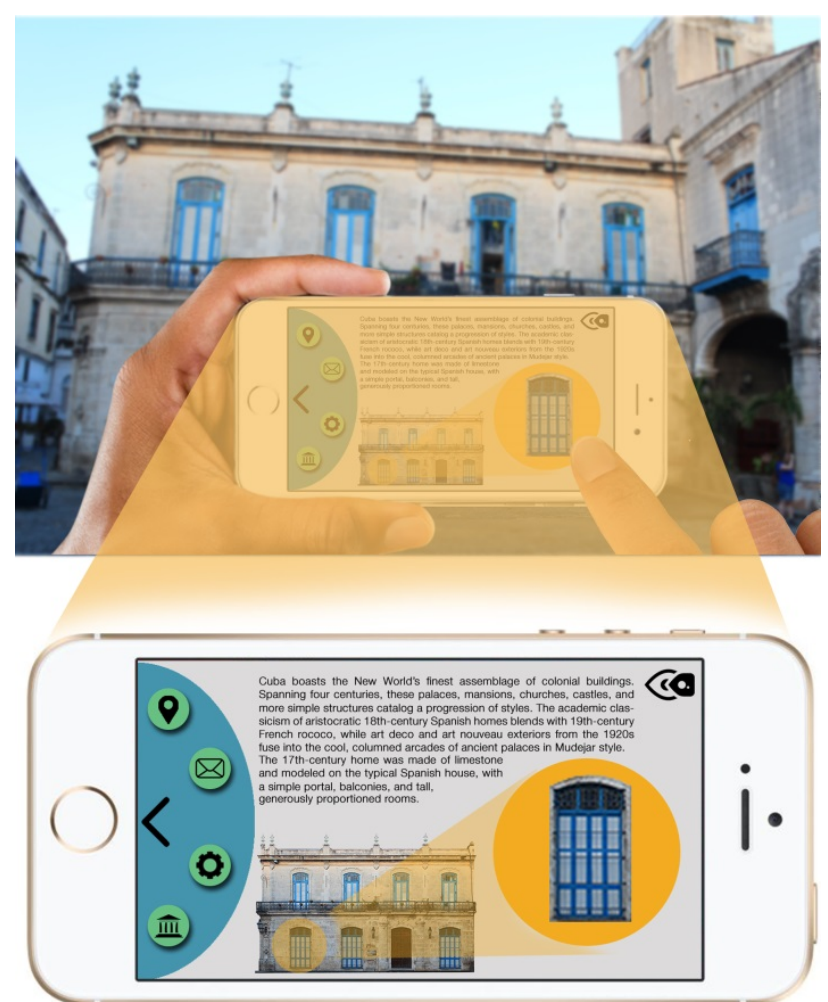

Figure 8. Example of an application of aumented reality (Casa de Baños - Plaza de la Catedral)
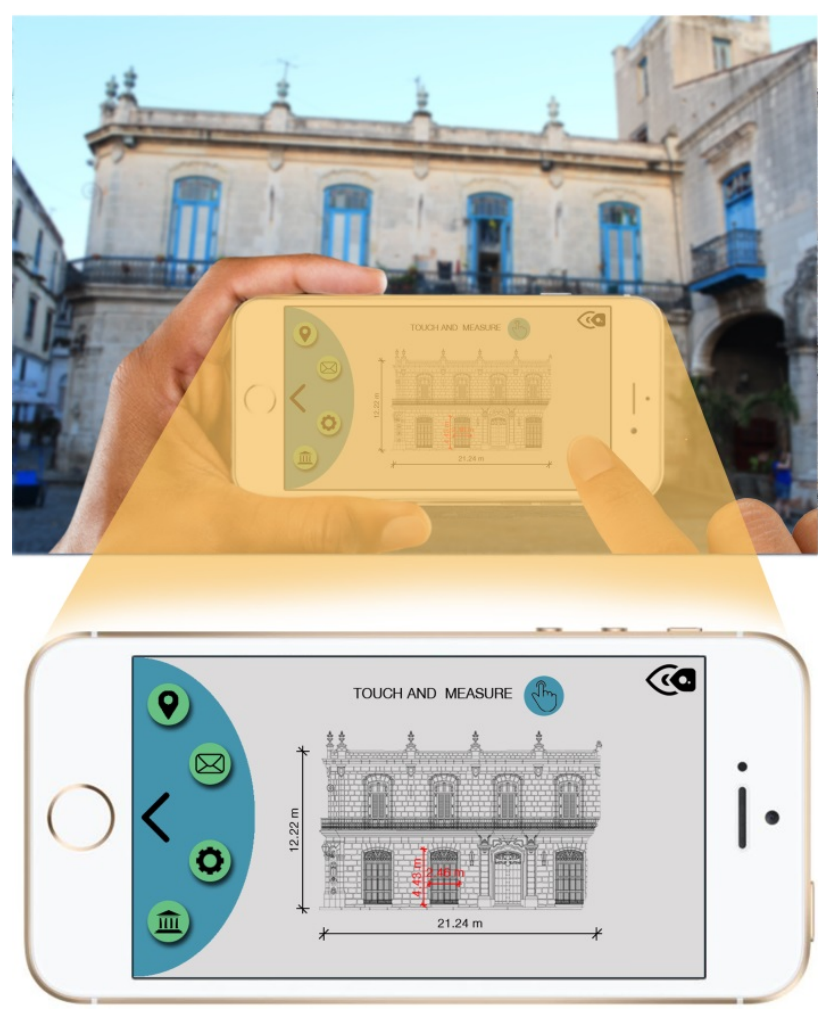

Figure 9. Example of an application of aumented reality (Casa de Baños - Plaza de la Catedral) 

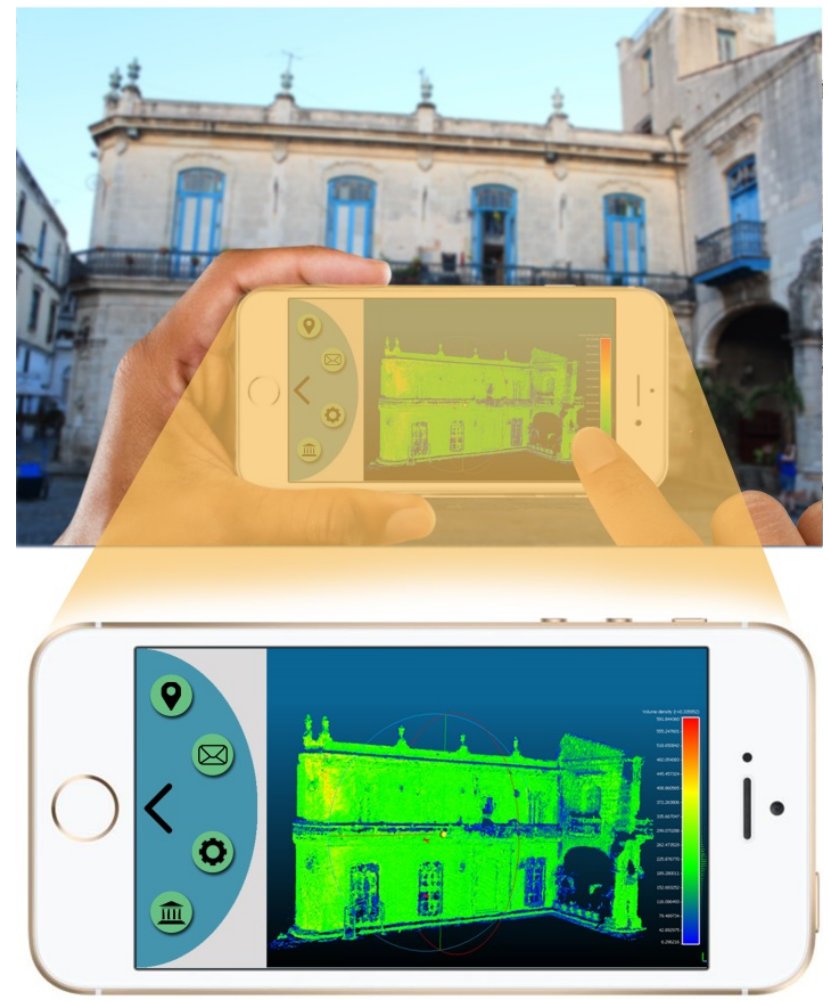

Figure 10. Example of an application of aumented reality (Casa de Baños - Plaza de la Catedral)
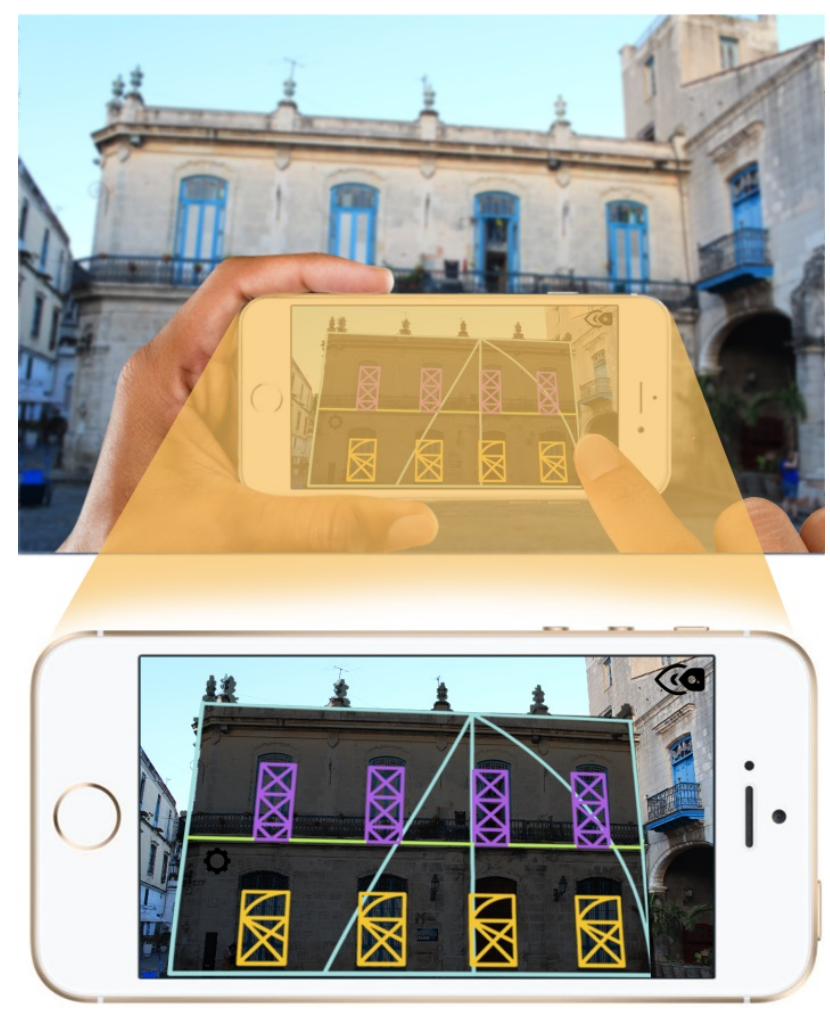

Figure 11. Example of an application of aumented reality (Casa de Baños - Plaza de la Catedral)
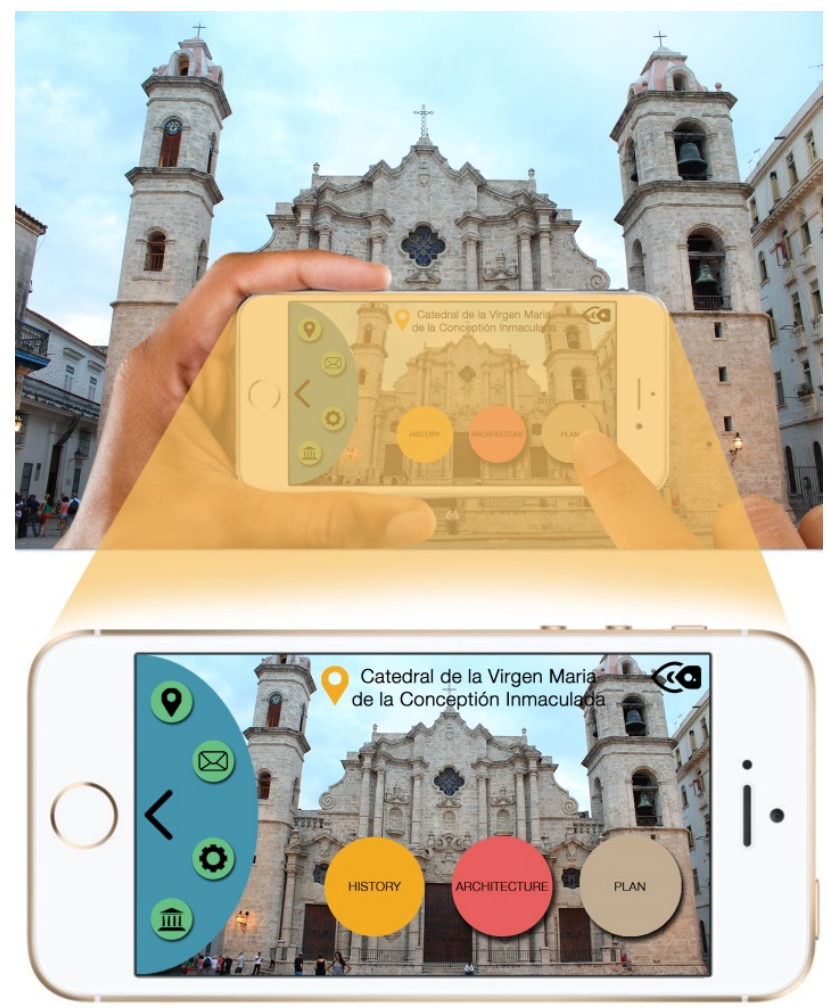

Figure 12. Example of an application of aumented reality (Catedral de la Virgen Maria de la Conceptión Inmaculada Plaza de la Catedral)
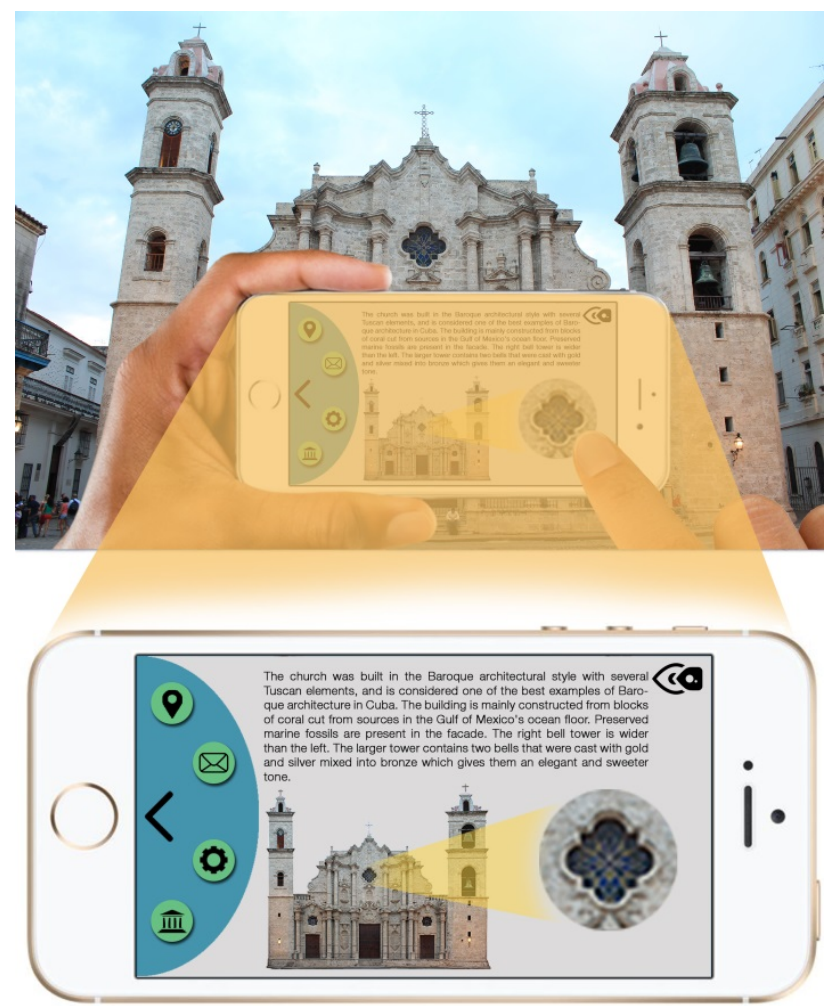

Figure 13. Example of an application of aumented reality (Catedral de la Virgen Maria de la Conceptión Inmaculada Plaza de la Catedral) 

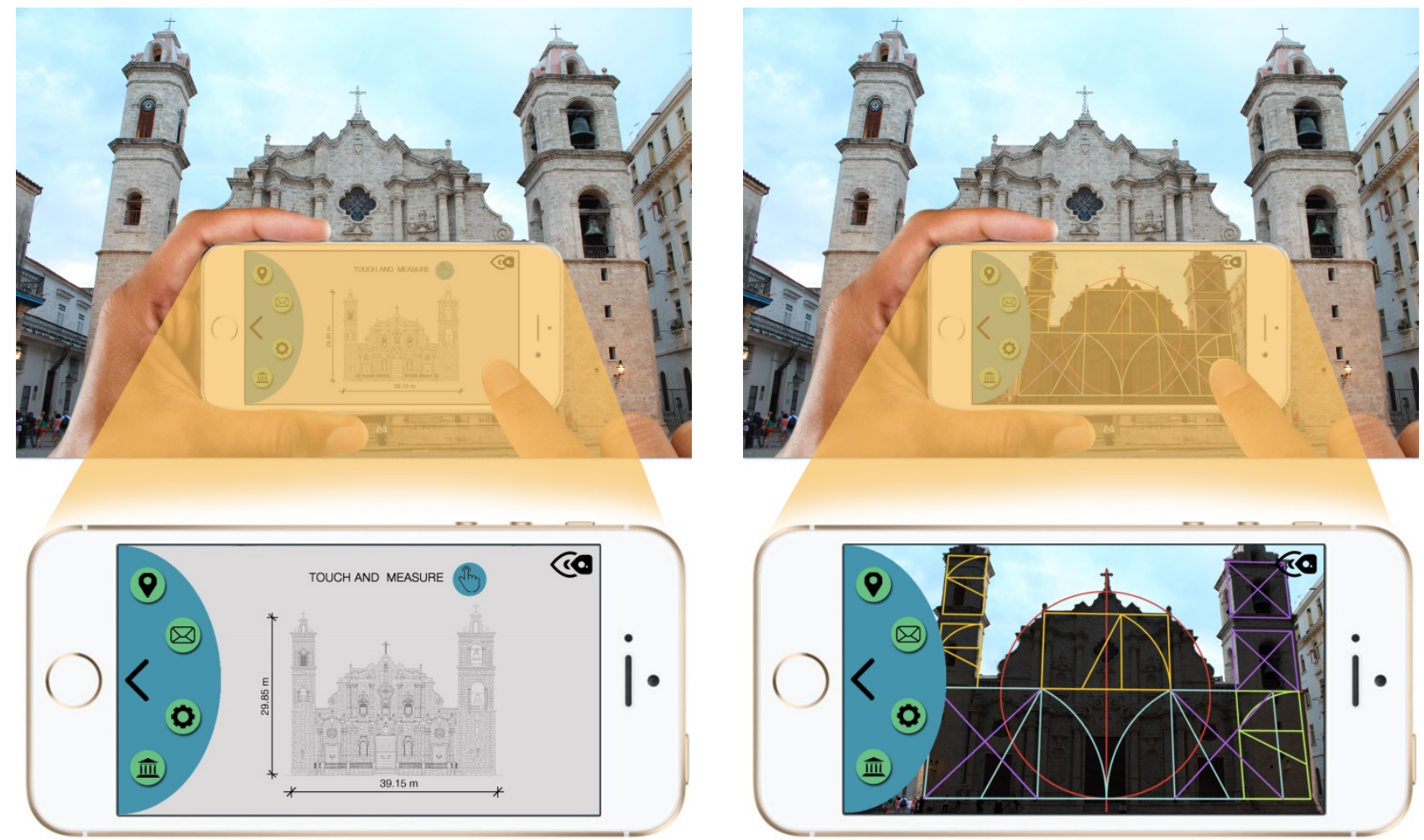

Figure 14. Example of an application of aumented reality (Catedral de la Virgen Maria de la Conceptión Inmaculada Plaza de la Catedral)
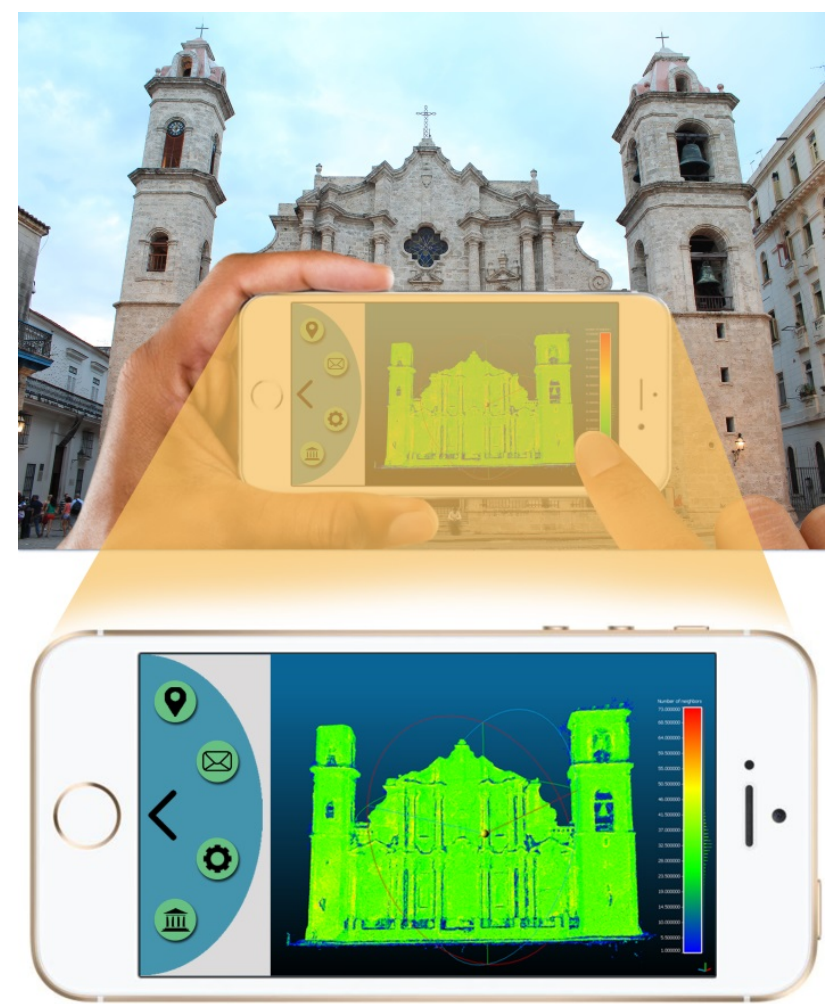

Figure 15. Example of an application of aumented reality (Catedral de la Virgen Maria de la Conceptión Inmaculada Plaza de la Catedral)

Figure 16. Example of an application of aumented reality (Catedral de la Virgen Maria de la Conceptión Inmaculada Plaza de la Catedral)

Augmented reality apps make it possible to coniugate the current state of a specific place's visualization to a series of information. Structure from motion and visualization tools represent applications for knowledge, comprehension and communication of cultural heritage. Particularly focusing on existing heritage the 3D model achieved by the structure for motion technique, together with $1 \mathrm{D}$ and $2 \mathrm{D}$, encourage a communicative and multidirectional flux in which information are differentiate and structured. The case study on Old Havana's heritage (AA.VV., 2009) is centered on virtual reconstruction and its representation through augmented reality. This technology is helping out the development of a mobile app which would give the possibility to see $1 \mathrm{D}, 2 \mathrm{D}$ and $3 \mathrm{D}$ data by using a simple smartphone, like for example current panorama's overlapping. It's the first kind of augmented reality on Cuban cultural heritage (AA.VV., 2015) ever experimented in architecture's field. A selection of images and models is geographically "fixed" on 3D space and coordinates are employed to accurately align visualizations from a specific position, for some of them contextual information are given with available additional resources. Every $1 \mathrm{D} / 2 \mathrm{D} / 3 \mathrm{D}$ object is geo-codified with the aim of achieving an user friendly app which could visualize data by pointing the phone on a specific position, choosing among images, drawings and models and watching visual overlaps through the camera's display. As the starting point we decided to oversee the range of augmented reality's technology to identify the most promising one to pursue the developing of an AR app focused on Havana and all its problems. Considering the way in which the technologic world is quickly evolving and changing we decided to investigate those which will probably be the most used platforms in the upcoming years. We examined the possibilities to understand real points of strengths and weakness of every available technology, seen that not always the promoted 
qualities are the effective ones. We realized that $\mathrm{AR}$ technologies can be basically divided in two kinds of approaches: one combining sensor's data with a modern smartphone, like GPS and accelerometer to efficiently suppose the current user's position and where he's looking at, the second one analyzes the images framed by the phone's camera to determinate what is actually visible around the user and where the objects are related with him (You, Azuma, Neumann, 1999). We decided to put our attention on Layar, Junaio, Sekai Camera Wikitude API e Worlds. Personalized Apple and Android apps are available on the market, or frameworks owning leader enterprises in this sector (like Wikitude and others) on which we carried out an analysis to identify problems which could influence the evolution of HabanApp.

Furthermore we analyzed the level of accuracy of smartphone's GPS as a tool that can give real visualization within the complex Havana's urban texture. We tried to understand if the technology would be able to position correctly 1D, 2D and 3D virtual objects contemporary giving augmented reality data (Reitmayr, Drummond, 2006). Using smartphone's cameras (ARToolKIt or Vuforia, for example) requires big control on the environment, a marker has to be physically positioned and a 3D model has to be created, in which the system could know where points of reference are fixed; the critical point here is that variations in lightning conditions could compromise the results. Photogrammetric tridimensional structure from motion will be employed as a reference basis to a proper alignment and dimensioning.

The most common approach is the one using those sensors included in the smartphone. The interested augmented reality data resource is the one giving all the information about the portion of the city currently framed by the camera. The compass gives all the information on the device's orientation and the accelerometer points out how the smartphone is moving in space. Together with the GPS, this gives the possibility to develop an AR app (Redondo, 2012) .

To create a good augmented reality app the first step is that of assigning the virtual object (image, drawing, 3D structure from motion, etc.) latitude and longitude's coordinates. To arrange data as overlays in 3D space is essential, and so is fundamental that coordinate's data position the images in the proper angulation, direction and scale in 3D scale. Especially images and model data would have an absolute positioning in space which allows them to be accurately aligned with the current panorama positioning (Gil, Santacana. 2013).

That's possible thanks to Google Street View and in particular Google maps offline. For this reason every recollecting and tracing step is essential. It has to be considered that elaboration's operations are meant to generate images to be visualized on a small mobile device's screen. For example in Layar, image's dimension has to be less than $75 \mathrm{~kb}-640 \times 480$. A relevant problem when dealing with a so compact urban environment like Havana's one is data overlaps due to an excessive quantity of information on buildings.

For this reason it is necessary to project the points (POI) in a definite way by fixing a minimum distance between two points which wouldn't interfere with data. Having more data connected to a single position can create some difficulties in visualizing information (Figure 17). It is important to give priority to the points of interest (POI) or to limit the number of available points of interest, to add interfaces for POI's research is another way to manage the density.

Several difficulties emerge during the concept phase to develop augmented reality apps, especially when dealing with some cities characterized by a dense and compact urban texture like Havana's one. More than deciding the AR framework to be used (Layar, ARToolkit, etc.), it is necessary to pay attention to those points of interest that must be included and on how to visualize information that the user will have to find, on the reason and the way those points have to be represented, on which geographical spot users would expect to obtain results and with which methods they would filter and look for possible results.

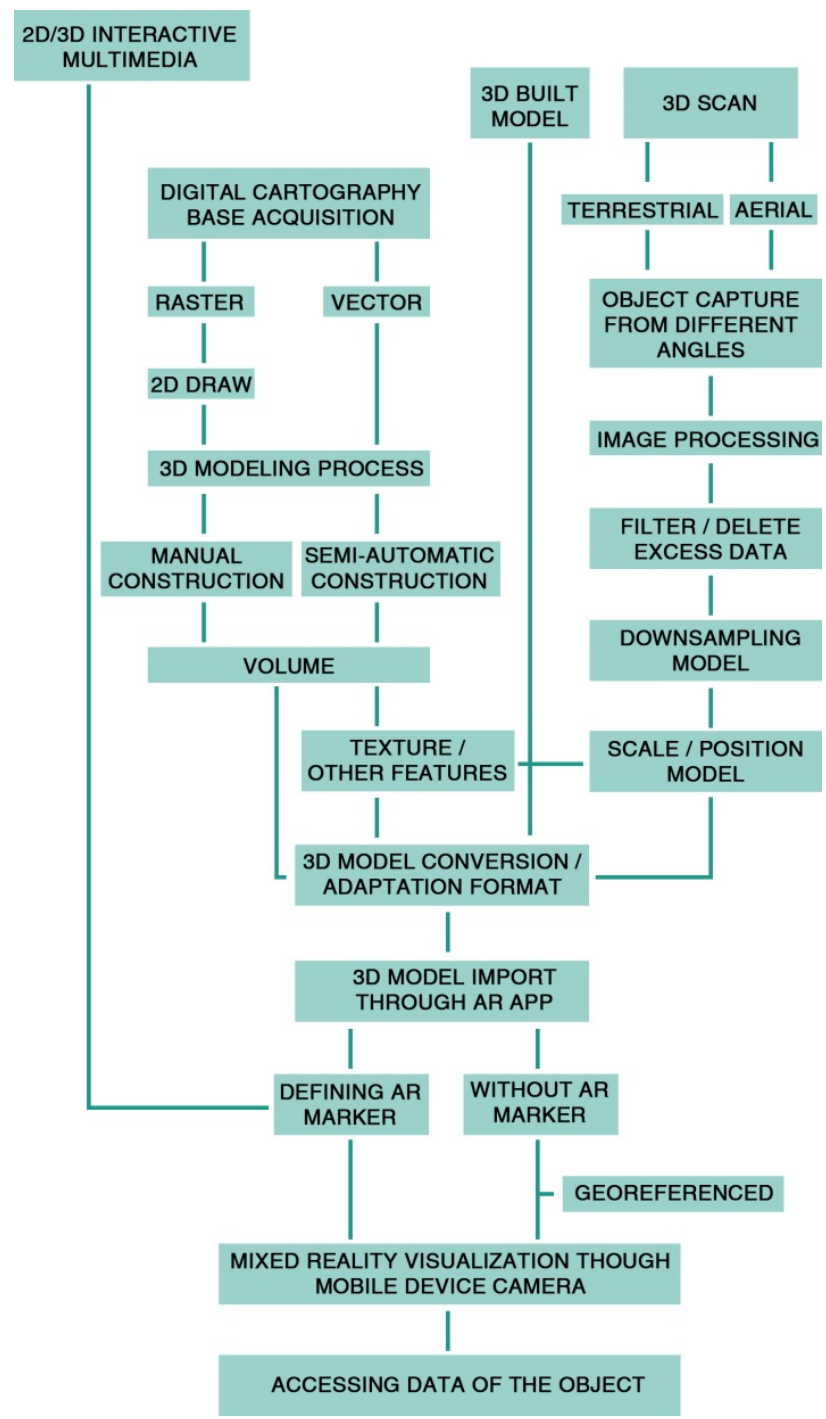

Figure 17. Approach to model and their visualisation in an augmented reality environment

\section{CONCLUSION}

Augmented reality apps introduce themselves as a tool of intersection between history and memory. Augmented reality mixes images from the real world with other kinds of data (in this case historical pictures, $1 \mathrm{D} / 2 \mathrm{D}$ and $3 \mathrm{D}$, drawings, etc.). The main purpose is to create a tool generating an continuous experience in which digital objects seems to take on a life on its own. This illusion's not easy to maintain especially in a context like Old Havana's one, where GPS devices are still not that accurate and the urban texture is various and stratified, it can lead to imprecise data bouncing and so point's choice is essential. Augmented reality can generate a combination of physical world's vision and digital representation with a simple click. Future research are developing in this way, investigating on new functionalities to valorize such a beautiful heritage like Cuban one. 


\section{REFERENCES}

AA.VV., 2011. La plaza Vieja de La Habana - proceso de recuperaciòn, ed. Consejerìa de Obras Pùblicas y Vivienda, Sevilla.

AA.VV., 2009. Regulaciones Urbanisticas Ciudad de La Habana - La Habana Vieja - Centro Historico, ed. Boloña, La Habana.

AA.VV., 2009. Manejo y gestiòn de centros històricos, ed. Boloña, La Habana.

AA.VV., 2015. Monumentos nacionales de la Repùblica de $\mathrm{Cuba}$, ed. Collage Ediciones, La Habana.

AA.VV., 1998. Guì de arquitectura, ed. consejo editorial, La Habana.

Bedoya Pereda, F., 2008. La Habana desaparecida, ed. Boloña, La Habana.

Bonacini, E., 2011. Nuove tecnologie per la fruizione e la valorizzazione del patrimonio culturale, Aracne Editrice, Roma.

Bonacini E., 2014. La realtà aumentata e le app culturali in Italia: storie da un matrimonio in mobilità, in: Il Capitale Culturale. Studies on the Value of Cultural Heritage, IX, EUM Edizioni Università di Macerata, Italy, pp. 89-121.

Garcia Santana, A., 2009. Urbanismo y arquitectura de la Habana Vieja - siglos XVI al XVIII, ed. Boloña, La Habana.

Gil, T. and Santacana, J. 2013. De lo real a lo digital: la arqueología reconstructiva y la obtención de imágenes virtuales para la investigación en la didáctica del patrimonio. HER\&MES, 13, pp. 16-35.

Mohammed-Amin R. K., 2010. Augmented reality: A narrative layer for historic sites. MEDes (CMD), University of Calgary.

Redondo, E. 2012. La ciudad como aula digital. Enseñando urbanismo y arquitectura mediante mobile learning y la realidad aumentada. ACE: Arquitectura, Ciudad y Entorno. 19, pp. 2754

Reitmayr, G. and Drummond, T., 2006. Going Out: Robust Model-based Tracking for Outdoor Augmented Reality. Proc. IEEE ISMAR'06, Santa Barbara, USA, pp. 109-118

You, S., Azuma, R. and Neumann, U., 1999. Hybrid iner- tial and vision tracking for augmented reality registration. In: IEEE VR 99, Houston, USA, pp. 260-268.

Venegas Fornias, C., 2003. Plazas de intramuro, ed. Mayra Fernàndez Peròn, La Habana. 